\title{
Amanah dan Kepuasan Konsumen dalam Memprediksi Produktivitas Rider Ojek Online
}

\author{
Fidia Oktarisa*, Citra Anisa Nanda, Desty Diandini Adityanti, Ihsanul Hakiki, Arief \\ Fahmie \\ Universitas Islam Indonesia \\ Email : *tarisafidia@gmail.com
}

\begin{abstract}
The existence of the rider ojek online as one of the impact of technology in the transportation industry. It is important for the company to review the productivity, as a form of achievement in providing satisfaction to customers by holding the value of "amanah". The researcher are interested to explain the correlation between customer satisfaction and "amanah" in predicting the productivity of the rider ojek online. The sampling techniques used in this research is purposive sampling. The data collection using the scale of "amanah" and the scale of customer satisfaction, the subject 112 customers and for the productivity variables rider using 112 productivity survey data through the personal account the rider ojek online with the method of the interview. The results of multiple linear regression analysis shows that the value of $\mathrm{F}(2.109)=0.62, \mathrm{p}<0,540$, with $\mathrm{R} 2=0.01$ stated that the significantly consumer satisfaction and "amanah" does not affect the achievement of the productivity rider ojek online PT.X.
\end{abstract}

Keyword: "amanah", consumer satisfaction, productivity.

Keberadaan rider ojek online sebagai salah satu dampak perkembangan teknologi di industri transportasi. Penting bagi perusahaan untuk meninjau produktivitas, sebagai bentuk pencapaian dalam memberikan kepuasan terhadap pelanggan dengan memegang nilai amanah sebagai salah satu keyakinan dalam menjalankan sistem online. Sehingga peneliti tertarik melihat korelasi antara kepuasan pelanggan dan amanah dalam memprediksi produktivitas rider ojek. Teknik sampling yang digunakan pada penelitian ini adalah purposive sampling. Pengumpulan data menggunakan skala amanah dan skala kepuasan konsumen, dengan jumlah subjek 112 pelanggan dan untuk variabel produktivitas rider menggunakan 112 data survey produktivitas melalui akun pribadi rider ojek online dengan metode wawancara. Hasil analisis regresi linier berganda menunjukkan bahwa nilai $\mathrm{F}$ $(2,109)=0,62, p<0,540$, dengan $\mathrm{R} 2=0,01$ menyatakan bahwa secara signifikan kepuasan konsumen dan amanah tidak memberi pengaruh terhadap pencapaian produktivitas riderojek online PT. $X$.

Kata kunci: amanah, kepuasan konsumen, produtivitas.

\section{PENDAHULUAN}

Ilmu pengetahuan dan teknologi yang berkembang pesat beberapa tahun terakhir ini dan membawa perubahan yang signifikan terhadap gaya hidup. Menurut Minor dan Mowen (2002), gaya hidup menunjukkan bagaimana orang hidup, bagaimana membelanjakan uangnya, dan bagaimana mengalokasikan waktu mereka.

Kemudahan yang ditawarkan oleh teknologi terbukti mampu merubah gaya hidup, selain itu teknologi juga telah 
membantu manusia dalam meringankan dan mempermudah manusia dalam menjalankan aktivitas-aktifitas sehariharinya. Berdasarkan situs https://www.go-jek.com/salah satu situs resmi perusahaan penyedia jasa layanan transportasi yang berbasis online, mencantumkan testimoni dari beberapa pelanggan jasa layanan transportasi tersebut yang menyatakan bahwa layanan jasa transportasi online sangat membantu aktivitas sehari-hari. Hasil penelitian Wulandari (2016) menunjukkan bahwa transportasi online belum diatur dalam undang-undang terkait lalu lintas dan angkutan jalan, namun keberadaannya saat ini menjadi modal transportasi publik bagi masyarakat, terutama di Daerah Khusus Ibukota Jakarta karena telah memenuhi harapan sebagai mode transportasi yang diinginkan dan dibutuhkan masyarakat. Pencapaian efektivitasnya sudah baik, namun masih belum optimal pada beberapa pelayanannya, seperti rentang waktu tempuh perjalanan, pelayanan pengemudi kepada pengguna, sistem aplikasi, keamanan, keselamatan, dan tarif baru pada biaya yang dibebankan pada jarak dekat maupun jarak jauh.

Menurut hasil wawancara terhadap salah satu rider ojek online menyebutkan bahwa beberapa faktor yang mempengaruhi tingkat permintaan dan kinerja layanan rider ojek online antara lain ditentukan oleh faktor internal dan eksternal. Faktor eksternal yaitu tingkat permintaan, jumlah pengendara ojek lain yang online, mobile, cuaca dan sistem. Sedangkan faktor internal terdiri dari tingkat motivasi dan kondisi kesehatan.

Sedarmayanti (Malonda, 2013) menjelaskan bahwa produktivitas pada hakekatnya merupakan motif ekonomi untuk memperoleh hasil sebanyakbanyaknya dengan biaya sekecil-kecilnya, bagaimana menghasilkan atau meningkatkan hasil barang dan jasa setinggi mungkin dengan memanfaatkan sumber daya secara efisien. Menurut Hasibuan (2010) produktivitas kerja merupakan perbandingan yang dimiliki baik secara perorangan ataupun tim di dalam organisasi tersebut.

Anggraeni (2015) pada penelitiannya mengungkapkan bahwa produktivitas kerja terdiri dari tiga aspek yaitu, produktivitas sebagai keluaran fisik per unit dari usaha produktif, produktivitas merupakan keefektifan dari penggunaan tenaga kerja dan peralatan, kemudian semua hal tersebut mengarah pada tujuan yang sama, bahwa produktivitas kerja adalah rasio dari hasil kerja dengan waktu yang dibutuhkan untuk menghasilkan produk dari seseorang tenaga kerja. Produktivitas pada penelitian ini dilihat melalui pencapaian jumlah order sesuai dengan ketetapan dari sistem, pendapatan harian diluar dari insentif dan pemberian rate bintang kepada rider ojek online.

Produktivitas rider ojek online untuk satu perusahaan dengan yang lain berbedabeda, hal tersebut tergantung dari kebijakan masing-masing, termasuk mengenai kompensasi dan benefitnya. Namun, pengaturan sistem dan kebijakankebijakan yang dibuat oleh perusahaan tidak lepas dari indikator penilaian kepuasan pelanggan sebagai salah satu penilaian utama.

Menurut Giese dan Cote (2000) kepuasan konsumen secara umum mengarah kepada tiga komponen utama, yaitu: respon (tipe dan intensitas) kepuasan konsumen merupakan respon emosional dan juga kognitif. Intesitas responnya mulai dari sangat puas dan menyukai produk sampai sikap yang apatis terhadap produk tertentu. Selanjutnya, fokus performansi objek disesuaikan pada beberapa standar. Nilai standar ini secara langsung berhubungan dengan produk, konsumsi, keputusan berbelanja, penjual 
dan toko. Komponen ketiga adalah waktu respon yang dapat terjadi pada waktu tertentu, antara lain setelah konsumsi, setelah pemilihan produk atau jasa berdasarkan pengalaman akumulatif. Durasi kepuasan mengarah kepada berapa lama respon kepuasan itu berakhir.

Menurut Mar'ati dan Sudarwanto (2016) harga dan kualitas layanan mempengaruhi kepuasan pelanggan. Faktor kualitas layanan yang dimaksud bergantung pada sistem, teknologi, dan sumberdaya manusia. Sebagaimna faktor sumberdaya manusia memberi kontribusi sebesar 70\%. Selanjutnya, menurut Agyapong (Mar'ati \& Sudarwanto, 2016) menyatakan dimensi kualitas layanan seperti tangibility, kehandalan, responsiveness, assurance, dan empati secara signifikan mempengaruhi sikap pelanggan dalam hal mendapatkan kepuasan.

Terdapat beberapa faktor utama kepuasan konsumen salah satu diantaranya kualitas produk dan pelayanan. Kualitas produk dan pelayanan merupakan salah satu hal penting, di mana konsumen akan merasa puas apabila mereka mendapat pelayanan yang lebih baik serta produk yang ditawarkan sesuai keinginan konsumen (Tjiptono \& Chandra, 2011).

Lovelock dan Wright (2007) menyatakan bahwa, kepuasan adalah keadaan emosional, reaksi setelah pembelian mereka, dan dapat berupa kemarahan, rasa tidak puas, kejengkelan, netralitas, kegembiraan, dan kesenangan. Kepuasan dipengaruhi oleh perbandingan layanan yang dipahami dengan pelayanan yang diharapkan, dan sebagai reaksi emosional jangka pendek pelanggan terhadap kinerja pelayanan tertentu. Kepuasan konsumen terhadap perusahaan jasa diartikan sebagai suatu keadaan di mana harapan konsumen terhadap suatu pelayanan sesuai dengan kenyataan yang diterima mengenai pelayanan yang diberikan kepada konsumen. Jika pelayanan suatu perusahaan jasa tersebut jauh di bawah harapan konsumen maka konsumen akan kecewa. Sebaliknya, jika layanan yang diberikan memenuhi harapan konsumen, maka konsumen akan merasa puas.

Kepuasan konsumen terhadap perusahaan jasa dapat diartikan sebagai suatu keadaan di mana harapan konsumen terhadap suatu pelayanan sesuai dengan kenyataan yang diterima, mengenai pelayanan yang diberikan kepada konsumen. Jika pelayanan suatu perusahaan jasa tersebut jauh di bawah harapan konsumen maka konsumen akan kecewa. Sebaliknya, jika layanan yang diberikan memenuhi harapan konsumen, maka konsumen akan merasa puas.

Harapan konsumen dapat diketahui dari pengalaman mereka sendiri saat menggunakan pelayanan suatu perusahaan jasa, omongan orang lain dan informasi iklan (Panjaitan, 2016). Band (Nasution, 2005) menjelaskan bahwa kepuasan tercapai ketika kualitas memenuhi dan melebihi harapan, keinginan, serta kebutuhan konsumen. Sebaliknya, bila kualitas tidak memenuhi dan melebihi harapan, maka keinginan dan kebutuhan konsumen tidak tercapai. Konsumen yang tidak puas terhadap barang atau jasa yang dikonsumsinya akan mencari perusahaan lain yang mampu menyediakan kebutuhannya.

Menurut Mar'ati dan Sudarwanto (2016) harga dan kualitas layanan mempengaruhi kepuasan pelanggan. Faktor kualitas layanan yang dimaksud bergantung pada sistem, teknologi, dan sumberdaya manusia. Sebagaimna faktor sumberdaya manusia memberi kontribusi sebesar 70\%. Selanjutnya, menurut Agyapong (Mar'ati \& Sudarwanto, 2016) 
menyatakan dimensi kualitas layanan seperti tangibility, kehandalan, responsiveness, assurance, dan empati secara signifikan mempengaruhi sikap pelanggan dalam hal mendapatkan kepuasan.

Terdapat beberapa faktor utama kepuasan konsumen salah satu diantaranya kualitas produk dan pelayanan. Kualitas produk dan pelayanan merupakan salah satu hal penting, di mana konsumen akan merasa puas apabila mereka mendapat pelayanan yang lebih baik serta produk yang ditawarkan sesuai keinginan konsumen (Tjiptono \& Chandra, 2011). Merupakan sebuah tanggung jawab yang besar bagi rider ojek online untuk dapat memberikan pelayanan sesuai dengan permintaan dari konsumen. Menunaikan semua apa yang telah menjadi kewajiban untuk ditunaikan, serta betulbetul memperhatikan dan tidak meremehkan amanah yang telah dipikulnya.

Amirin (2007) menjelaskan bahwa amanah merupakan suatu kepercayaan yang diberikan kepada seseorang untuk ditunaikan kepada yang berhak, serta orang yang amanah merupakan orang yang dapat menjalankan tugas yang diberikan. Amanah juga merupakan suatu kepercayaan yang diberikan kepada seseorang untuk ditunaikan kepada yang berhak serta orang yang amanah merupakan orang yang dapat menjalankan tugas yang diberikan (Amirin, 2007).

Selanjutnya, amanah menurut Antonio (2005) adalah segala hak yang diserahkan oleh pemberi kepada penerima hak, di mana penerima hak adalah orang yang dapat diandalkan, menjaga hak sampai diserahkan kembali dengan penuh tanggung jawab serta apa adanya, bebas dari kepentingan pihak luar, dan mengembalikan kepada pemberi hak dalam jangka waktu yang telah ditentukan.
Adapun aspek-aspek amanah yang dikemukakan oleh Antonio (2005) adalah justice (adil), fulfililingcommitment atau menepati janji, reliability atau dapat diandalkan, transparence atau keterbukaan, independence atau kemandirian, emotional and physical fitness (kesehatan jiwa dan fisik), accountable and responsible (akuntabilitas dan responsibilitas)

Pendapat tentang amanah tersebut dapat diuraikan bahwa tingkat keamanahan seorang rider ojek online dapat mempengaruhi tingkat kepuasan pelanggan. Sedangkan produktivitas, menurut teori diatas ditentukan antara lain oleh kualitas kerja dan tanggung jawab, yang merupakan aspek-aspek dalam amanah.

Berdasarkan latar belakang diatas, penulis ingin menguji apakah benar amanah dan kepuasan pelanggan memiliki keterkaitan dan pengaruh terhadap produktivitas riderojek online. Oleh karena itu penulis akan menempatkan amanah dan kepuasan pelanggan sebagai variabel bebas atau prediktor yang akan diuji untuk melihat apakah amanah dan kepuasan konsumen sebagai varibel bebas dapat memprediksi produktivitas rider ojek online.

\section{METODE}

Penelitian ini merupakan jenis penelitian kuantitatif korelatif dengan menggunakan teknik analisis regresi linier berganda untuk menguji hipotesa penelitian. Pengumpulan data penelitian menggunakan skala likert yang terdiri dari skala amanah dan skala kepuasan konsumen yang diturunkan dari aspekaspek masing-masing variabel. Penyebaran skala dilakukan secara online menggunakan fasilitas google form dari Google.

Sebelum digunakan untuk pengumpulan data penelitian, kedua skala 
tersebut disebar untuk uji coba skala. Hasil uji coba menggunakan validitas dan reliabilitas menunjukkan bahwa skala amanah memiliki reliabilitas dengan nilai alpha cronbach 0,713 dan nilai alpha cronbach untuk skala kepuasan konsumen 0,943 serta aitem dari masing-masing valid atau tidak ada aitem yang gugur dengan rata-rata nilai validitas di atas 0,6 yang artinya seluruh aitem dapat disebar sebagai instrumen penelitian.

Selanjutnya skala disebar untuk mendapatkan data penelitian. Penyebaran skala dilakukan melalui google form dari Google selama 3 hari yaitu dari tanggal 12 Desember 2017 sampai dengan 31 Desember 2017. Setelah data penelitian terkumpul, data dianalisis menggunakan teknik analisis regresi yang merupakan teknik analisis data untuk mengkaji hubungan antar variabel dan meprediksi variabel tertentu (Kutner, Nachtsheim, \& Neter, 2004). Analisis regresi yang digunakan untuk penelitian ini yaitu analisis regresi linier berganda karena terdapat dua variabel bebas sebagai prediktor variabel dependen (Widarjono, 2007). Analisis data penelitian dibantu oleh aplikasi PSPP untuk mempermudah peneliti dalam mengolah data penelitian.

Proses pengambilan data penelitian ini dilakukan dengan dua cara yaitu menggunakan kuisioner online dan pengambilan data secara wawancara langsung dengan riders ojek online dengan lokasi penelitian adalah Kota Yogyakarta dan sekitarnya. Pengambilan data dilakukan selama tiga hari mulai tanggal 16 Desember 2017 sampai dengan 18 Desember 2017 untuk penyebaran kuisioner dan wawancara langsung dengan rider ojek online untuk mendapatkan data mengenai produktivitas ridertersebut.

Populasi penelitian ini adalah pelanggan ojek online dan riderojek online yang ada di Daerah Istimewa Yogyakarta. Teknik sampling penelitian ini adalah purposive sampling di mana subjek dipilih berdasarkan kriteria subjek penelitian yaitu subjek yang memiliki akun ojek online, pernah menggunakan jasa riderojek online, dan berada di Wilayah Kota Yogyakarta dan sekitarnya. Sampel penelitian dipilih sesuai kriteria sampel penelitian, di mana dari keseluruhan jumlah populasi peneliti menemukan sebanyak 112 orang yang memenuhi kriteria untuk menjadi sampel sebagai konsumen ojek online dan 112 sampel riderojek online. Subjek merupakan pegawai dan pengguna jasa ojek online yang berada di Kota Yogyakarta dan sekitarnya.

Pengumpulan data penelitian menggunakan pelaporan diri berupa angket yang terdiri dari dua skala yaitu skala amanah dan skala kepuasan konsumen. Penyusunan skala amanah berdasarkan aspek-aspek amanah dari beberapa ahli dan skala kepuasan konsumen disusun berdasarkan aspekaspek kepuasan konsumen dari beberapa ahli yang kemudian diturunkan menjadi indikator dalam bentuk aitem-aitem atau pernyataan. Penyebaran masing-masing skala menggunakan kuisioner online melalui fasilitas google form dari google. Kemudian pengumpulan data produktivitas riderojek online menggunakan metode wawancara langsung.

\section{HASIL DAN PEMBAHASAN}

\subsection{HASIL}

Penelitian ini dilakukan untuk menguji hipotesis mayor dari penelitian ini yaitu variabel amanah dan variabel kepuasan konsumen berpengaruh signifikan terhadap produktivitas riderojek online. Data penelitian terdiri dari data surveyuntuk mengukurproduktivitas 
riderojek online, data dari skala amanah dan data dari skala kepuasan konsumen. Adapun hasil uji analisis regresi linier berganda dengan menggunakan aplikasi PSPP, dapat dilihat pada tabel.1 berikut ini.

Tabel 1. Anova Produktivitas

\begin{tabular}{lccccc}
\hline & Sum of Squares & Df & Mean Square & $F$ & Sig. \\
\hline Regression & 20,60 & 2 & 10,30 & 0,62 & 0,540 \\
Rasidual & 1809,68 & 109 & 16,60 & & \\
Total & 1830,28 & 111 & & & \\
\hline
\end{tabular}

Berdasarkan hasil analisis regresi linier berganda untuk memprediksi produktivitas rider ojek online oleh kepuasan pelanggan dan amanah. Hasil analisis pada table. 1 menunjukkan terbukti

Tabel 2. Coefficients Produktivitas

\begin{tabular}{cccccc}
\hline & \multicolumn{2}{c}{$\begin{array}{c}\text { Unstandardized } \\
\text { Coefficients }\end{array}$} & $\begin{array}{c}\text { Standardized } \\
\text { Coefficients }\end{array}$ & $t$ & Sig. \\
\cline { 2 - 4 } & B & Std Error & Beta & & \\
\hline (Constant) & 9,38 & 3,62 & 0,00 & 2,59 & 0,011 \\
AMANAH & $-0,03$ & 0,06 & $-0,06$ & $-0,56$ & 0,577 \\
KK & 0,11 & 0,10 & 0,13 & 1,11 & 0,269 \\
\hline
\end{tabular}

Berdasarkan tabel. 2 atau tabel coefficients produktivitas dapat dilihat masing-masing variabel independen tidak terdapat pengaruh signifikan dalam memprediksi produktivitas riderojek online di mana nilai beta produktivitas dengan amanah dan kepuasan pelanggan sama dengan 9,38 0,11 (kepuasan konsumen) - 0,03 (amanah) atau 9,24. Korelasi amanah dalam memprediksi produktivitas tidak signifikan mempengaruhi dengan nilai $\mathrm{p}<0,577$ dan korelasi kepuasan konsumen dalam memprediksi produktivitas tidak signifikan mempengaruhi dengan nilai $\mathrm{p}<0,269$. Kepuasan konsumen diukur dari puas atau tidak puas, dan amanah diukur dari ada amanah atau tidak ada amanah. Baik kepuasan konsumen maupun amanah merupakan prediktor tidak signifikan $(\mathrm{F}(2,109)=0,62, \mathrm{p}<0,540)$, dengan R2 0,01. Selanjutnya, regresi berdasarkan masing-masing varibel bebas dapat dilihat pada table.2. 
secara keseluruhan maupun yang berhubungan dengan kebijakan pemerintah (Budiasih, 2012). Adapun faktor - faktor yang mempengaruhi produktivitas tergantung pada faktor manajemen, perencanaan, prosedur kerja yang efektif, komunikasi yang baik, sumber daya manusia yang lebih efektif, dan kebijakan yang dapat direfleksikan melalui faktor tenaga kerja, modal, manajemen, dan organisasi (Budiasih, 2012).

Produktivitas karyawan dalam sebuah perusahaan berdampak kepada produktivitas perusahaan itu sendiri, dalam hal pelayanan terhadap konsumen maka dimulai dari kebutuhan kemudian berujung pada persepsi pelanggan. Hal ini menurut Gazperz dapat diimplementasikan dalam interaksi antara karyawan dengan pelangan yang mencakup ketepatan waktu, terkait dengan kecepatan memberikan tanggapan terhadap keperluan - keperluan pelanggan; penampilan karyawan, berkaitan dengan kebersihan dan kecocokan dalam berpakain; kesopanan dan tanggapan terhadap keluhan berkaitan dengan bantuan yang diberikan dalam menyelesaikan masalah-masalah yang diajukan pelanggan (Prasetyo \& Wahyudin, 2003).

Berdasarkan hasil penelitian yang telah dilakukan menunjukkan bahwa produktivitas secara signifikan tidak dapat diprediksi oleh kepuasan konsumen, di mana kepuasan konsumen pada pelanggan ojek online yang diukur menggunakan skala kepuasan konsumen tidak memiliki hubungan yang signifikan terhadap produktivitas riderojek online. Hal ini terbukti dari hasil penelitian Bahrami (2012) bahwa kepuasan konsumen bukanlah faktor utama dalam mempengaruhi produktivitas karyawan seperti perawat dalam memberikan pelayanan kesehatan, melainkan loyalitas dan kompetensi yang dimiliki menjadi faktor utama meningkatnya produktivitas.

Produktivitas apabila dikaji secara kepercayaan agama Islam, bukanlah semata-mata hanya kepentingan duniawi. produktivitas terkait dengan amanah. Sebenarnya konsep ini sudah dijelaskan dalam ayat dan hadis yang berbicara tentang produktivitas seseorang. Hanya saja belum terumuskan dalam sebuah konsep yang nyata sebagaimana perspektif islam. Produktif dalam bekerja tidak sekedar mengejar target yang telah menjadi tuntutan, apalagi dengan menghalalkan segala cara. Prosesnya harus menghadirkan nilai-nilai kebaikan dalam rangka ibadah dan mengharap keridhoan dari Allah subhanahu wata'ala (Fathoni, 2017). Penghayatan terhadap nilai atau makna hidup, agama, pengalaman, dan pendidikan harus diarahkan untuk menciptakan sikap kerja professional, sedangkan apresiasi nilai yang bersifat aplikatif akan membuahkan akhlakul karimah salah satunya amanah.

Berdasarkan hasil penelitian ini, distribusi amanah dalam produktivitas riderojek online tidak menjukkan pengaruh yang signifikan dalam memprediksi produktivitas, sehingga nilai-nilai amanah bukan menjadi salah satu faktor yang dapat meningkatkan produktivitas individu. Nilai-nilai kebaikan seperti amanah terkait dengan tanggung jawab hamba terhadap Tuhannya, tanggung jawab seseorang terhadap orang lain, penegakkan keadilan, kenyamanan secara psikologis, kesuksesan kehidupan di dunia, dan kehidupan selanjutnya (Samsudin \& Islam, 2015).

\section{KESIMPULAN}

Berdasarkan penelitian yang telah dilakukan, maka dapat disimpulkan bahwa amanah dan kepuasan konsumen, tidak dapat menjadi prediktor untuk melihat produktivitas rider ojek online PT. X. 
Selanjutnya hasil dari uji hipotesis, tidak terdapat pengaruh yang signifikan dari kedua variabel bebas dalam memprediksi produktivitas di mana kedua variabel tidak memberi pengaruh yang signifikan untuk memprediksi produktivitas rider ojek online PT. X. Maka dengan ditolaknya hipotesis tersebut, menunjukkan bahwa produktivitas pada rider ojek online PT. X tidak dipengaruhi oleh kepuasan konsumen dan amanah. Hal tersebut mengindikasikan bahwa terdapat faktor lain yang mempengaruhi produktivitas pada rider ojek online yang sifatnya eksternal dan tidak dapat diprediksiatau dikontrol, seperti faktor lingkungan (kemacetan dan antrian), sistem pada PT. X dan cuaca yang dapat mempengaruhi produktivitas rider ojek online. Oleh karena itu, ketiga faktor tersebut dapat dipertimbangkan untuk dapat diteliti lebih lanjut sebagai variabel pada penelitian selanjutnya.

\section{DAFTAR PUSTAKA}

Amirin, T. M. (2007). Kepemimpinan yang amanah. Dinamika Pendidikan

Anggraeni, L. S. (2015). Pengaruh Produktivitas, Efisiensi, Kepuasan Kerja Terhadap Perputaran Karyawan Bagian Marketing. Jurnal Ilmudan Riset Manajemen. 4 (5), 118

Antonio, M. S. (2005). Prophetic leadership and management wisdom. Jakarta: Tazkia Publishing

Bahrami, Hasanpour, Rajaeepour, Aghahosseni, Hodhodineghad. (2012). The relationship between organizational trust and nurse administrator's productivity in hospitals. Iranian Journal of Nursing and Midwifery Research, 17 (6)

Budiasih, Y. (2012). Struktur Organisasi, Budaya Kerja, Desain Kerja dan
Pengaruhnya

terhadap

Produktivitas Karyawan Studi

Kasus pada PT XX di Jakarta. Jurnal

Liquidity, 1 (2), 99-105

Fathoni, K. (2017). Analisis Konsep

Produktivitas Kerja Konvensional

Dalam Pandangan Islam Al Tijarah,

3(1), 1-14 p-ISSN: 2460-4089 e-ISSN: 2528-2948

Giese \& Cote. (2000). Academy of Marketing Science Review.

Defining Consumer Satisfaction, 2000 (1)

Hasibuan, M. S. P. (2010). Manajemen Sumber Daya Manusia. Jakarta: PT Bumi Aksara.

Kutner, M.H., Nachtsheim dan J, Neter. (2004) Applied linear regresion model. New York: McGraw-Hill Companies, Inc

Lovelock, C \& Wright, L. K. (2007). Manajemen Pemasaran Jasa. PT. Indeks: Jakarta, Indonesia

Malonda, V. (2013). Kepuasan Dan Motivasi Kerja Pengaruhnya Terhadap Produktivitas Kerja Karyawan Pt. Matahari Megamall Manado. Jurnal EMBA 969, 1 (3), 969-979,ISSN 2303-1174

Mar'ati, N. C. \& Sudarwanto, T. (2016). Pengaruh kualitas layanan dan harga terhadap kepuasan pelanggan jasa transportasi ojek online (studi pada konsumen gojek di surabaya). Jurnal Pendidikan Tata Niaga (JPTN), 3(3)

Mowen, J. C. \& Minor, M. (2002). Perilaku Konsumen. Jakarta. Erlangga

Nasution, M. N., (2005). Manajemen Mutu Terpadu (Total Quality Management). Edisi Kedua. Ghalia Indonesia, Bogor.

Panjaitan, J. E. (2016). Pengaruh Kualitas Pelayanan Terhadap Kepuasan Pelanggan pada Jne Cabang Bandung. Derema Jurnal Manajemen, 11(2), 265-289 
Prasetyo, E., \& Wahyuddin. (2003).

Pengaruh Motivasi dan Kepuasan

Kerja Terhadap Produktivitas Kerja

Karyawan Riyadi Palace Hotel di

Surakarta. Tesis (tidak diterbitkan).

Program Pascasarjana Universitas

Muhammadiyah Surakarta. Solo

Samsudin \& Islam. (2015). Value of alamanah in human' life. International Jurnal of Scientific and Research Publication, 5 (4)

Tjiptono, F., \& Chandra, G. (2011). Service, Quality \& Satisfaction. Yogyakarta: Andi.

Widarjono, A. (2007). Ekonometrika: teori dan aplikasi untuk ekonomi dan bisnis. Edisi Kedua. Yogyakarta: Ekonisia Fakultas Ekonomi Universitas Islam Indonesia.

Wulandari, W. (2016). Analisis Efektifitas Transportasi Ojek online Sebagai Pemilihan Moda Transportasi Di Jakarta (Studi Kasus : Go-Jek Indonesia). Skripsi. Universitas Esa Unggul Jakarta. 